April 2012

\title{
Macro, Meso, and Micro Research on Genocide: Gains, Shortcomings, and Future Areas of Inquiry
}

\author{
Evgeny Finkel
}

Scott Straus

Follow this and additional works at: https://digitalcommons.usf.edu/gsp

\section{Recommended Citation}

Finkel, Evgeny and Straus, Scott (2012) "Macro, Meso, and Micro Research on Genocide: Gains, Shortcomings, and Future Areas of Inquiry," Genocide Studies and Prevention: An International Journal: Vol. 7: Iss. 1: Article 7.

Available at: https://digitalcommons.usf.edu/gsp/vol7/iss1/7

This Articles is brought to you for free and open access by the Open Access Journals at Digital Commons @ University of South Florida. It has been accepted for inclusion in Genocide Studies and Prevention: An International Journal by an authorized editor of Digital Commons @ University of South Florida. For more information, please contact digitalcommons@usf.edu. 


\title{
Macro, Meso, and Micro Research on Genocide: Gains, Shortcomings, and Future Areas of Inquiry
}

\author{
Evgeny Finkel and Scott Straus ${ }^{1}$ \\ University of Wisconsin, Madison
}

\begin{abstract}
The article critically reviews the existing literature on genocide and mass violence and divides it according to different levels of analysis: macro, meso, and micro levels. We discuss the main theories and findings at each level of analysis and suggest avenues for further research. We argue that the literature on genocide should pay more attention to meso and micro levels of analysis. We also identify a number of other research problems, including conceptualization, selection bias, case comparability, the role of restraint, the question of change over time, and the need to engage in dialogue with the broader social science scholarship on political violence and intrastate conflict.
\end{abstract}

Key words: genocide, political violence, levels of analysis, social sciences

As a growing field of inquiry, the comparative study of genocide is more robust than ever; yet major problems and obstacles remain. Begun in the late 1970s and 1980s with seminal works by Leo Kuper, Helen Fein, Israel Charny, and Irving Louis Horowitz, ${ }^{2}$ the area of study remained relatively marginal to mainstream social sciences and history until the mid to late 1990s. Thereafter, the onset of cases in Central Africa and Eastern Europe, which drew widespread attention in policy and academic domains, stimulated major new interest from scholars. The net impact is substantial progress on a number of fronts, in particular broader comparative analysis, more sophisticated methods of comparison, and a raft of new and exciting theories, particularly at the macro level.

Yet a number of important problems continue to plague the field of study: conceptual disagreement (which in turn limits consensus on the universe of relevant cases), a tendency toward selection bias (with reliance on "positive" cases-i.e., cases where genocide occurred-rather than a focus on variation in outcomes, thus avoiding comparisons between situations where genocide occurred and those in which it did not), unit heterogeneity (the cases under comparison are quite diverse), an unhealthy academic cloistering (in particular, a lack of dialogue with kin literature on political violence), and a theoretical focus on invariant or slowly changing variables measured at the society and state levels of analysis. ${ }^{3}$ Most of these factors, we argue, substantially limit the field's ability to move forward and successfully address new research questions and agendas. In addition, we argue that meso-level analysis remains underdeveloped in the field of genocide studies and that micro-level analysis would gain from more attention to variation and to greater cross-case comparison.

Consistent with the mandate of this special issue of Genocide Studies and Prevention, our main purpose is to critically review the existing literature and suggest avenues for future research. In our case, the exclusive focus is on literature on the causes of genocide (and mass killing) and its dynamics, with a particular emphasis on comparative analysis. ${ }^{4}$ There is no easy way to neatly divide and classify this literature, which is

Evgeny Finkel and Scott Straus, "Macro, Meso, and Micro Research on Genocide: Gains, Shortcomings, and Future Areas of Inquiry," Genocide Studies and Prevention 7, 1 (April 2012): 56-67. (c) 2012 Genocide Studies and Prevention. doi: 10.3138/gsp.7.1.56 
interdisciplinary, diverse, and increasingly deep. Rather than clustering the literature into "generations," as one of us has done elsewhere, ${ }^{5}$ we borrow from the literature on civil war and choose to divide the literature according to different levels of analysis: namely macro, meso, and micro levels. A crucial caveat is in order: any short, critical, and broad-gauged analysis of the existing literature can do justice neither to the complexity and nuance of many authors' arguments nor to the breadth of research. The review is necessarily incomplete. Even so, we aim to provide a useful guide to the existing literature and to suggest areas of improvement for future work.

\section{Macro-Level Research}

In the interest of simplicity, we divide the macro-level literature into six major streams of argumentation about (1) intergroup relations, (2) regime type, (3) hardship and upheaval, (4) ideology, (5) leaders' strategy, and (6) modernity and development. Some theories cross these boundaries; some theories are multicausal. Yet, in the main, these different theoretical emphases provide a starting point for categorizing the existing macro-level literature on the origins of genocide.

The central claim made by scholars who stress intergroup relations is that the deep origins of genocide are fractious relations between groups in a society. For Kuper, "divided" societies in which populations disliked and distrusted each other are necessary conditions for the occurrence of genocide. ${ }^{6}$ For Fein, the idea that dominant groups in particular contexts define subordinate groups "outside the universe of obligation" is central to her explanation. ${ }^{7}$ More recently, Daniel Goldhagen has asserted that widespread eliminationist hatred is the root of genocide. ${ }^{8}$ Similarly, John Hagan and Wenona Rymond-Richmond stress racism in their recent book on Darfur. ${ }^{9}$ There are a number of causal mechanisms in this strand of literature. The main ones concern hatred, antipathy, and distrust on the part of a segment of the population toward another segment of the population. Dehumanization is another commonly stipulated mechanism. For large segments of a population to acquiesce to or support genocide, they must either be indifferent to or want the destruction of other segments.

The central claim made by scholars who stress regime type is that authoritarianism facilitates radicalization and the use of violence. The causal claims are present in two seminal works by Rudolph Rummel and Horowitz. ${ }^{10}$ They receive more contemporary empirical support in Barbara Harff's quantitative research as well as that of Kristine Eck and Lisa Hultman (though Jay Ulfelder and Benjamin Valentino's quantitative findings as well as those of Matthew Krain do not support a relationship between regime type and large-scale destruction). ${ }^{11}$ Although sometimes submerged in scholarship, the regime type literature posits two main mechanisms. On the one hand, the absence of democratic constraints in authoritarian states depresses opposition and thereby facilitates the escalation of extremism. On the other hand, the regular use of repression in an authoritarian system regularizes and normalizes the use of violence by states.

The central claim made by those scholars who stress hardship and upheaval is that certain factors create conditions within populations that in turn trigger violence and scapegoating toward other populations. As Ervin Staub and Peter Uvin have found, the central hypothesized mechanism in the literature is frustration-aggression, whereby deprivation or structural violence create anger and disappointment which are then channeled into aggression toward other populations. ${ }^{12} \mathrm{~A}$ related claim is that instability and upheaval (war, revolution, coups, or regime changes) create uncertainty and dislocation, which too can be directed toward out-groups. Harff argues that national upheaval is a 
key facilitating condition that interacts with pre-existing social cleavages which are polarized in crisis. ${ }^{13}$

Ideological arguments are diverse, but at the base the claim is that leader-level goals and ideational frameworks shape the policy choice of genocide. Scholars highlight different ideological content. Eric Weitz emphasizes commitments to utopia based on race and nation; Michael Mann emphasizes commitments to ethnic nationalism and perversions of democratic ideals; Ben Kiernan argues that ideological commitments to racism, agrarianism, expansionism, and the cult of antiquity are consistent themes across time in genocide cases; Jacques Semelin emphasizes commitments to purity in times of crisis. ${ }^{14}$ In some contrast to scholars who locate the origins of genocide in social or intergroup relations, scholars who emphasize ideology conceptualize the process leading to genocide as top-down. Some scholars also argue that ideology shapes processes of escalation and how leaders respond to contingency and constraints in times of crisis. ${ }^{15}$

Strategic arguments are similarly diverse, and similarly top-down, but the central claim is that leaders choose genocide for instrumental purposes to solve problems and achieve major goals. Ben Valentino's work is the most explicit, but other political scientists, such as Chip Gagnon, argue that politicians choose nationalism and persecution for instrumental purposes. ${ }^{16}$ Manus Midlarsky argues that the choice of genocide is exercised to protect state interests, emerging from realpolitik-political and strategic considerations rather than ideological ones-but he argues that the decision is imprudent and disproportionate. ${ }^{17} \mathrm{~A}$ related claim is that genocide and war have a strong causal connection. This claim is made, among others, by Martin Shaw; Valentino, Paul Huth, and Dylan Balch-Lyndsay and Ulfelder and Valentino argue that mass killing most likely emerges in the context of guerrilla civil war. ${ }^{18}$

Finally, a number of scholars link the destruction of civilian populations to underlying processes of modernization, development, and interstate competition. The claims are found in Zygmunt Bauman's seminal work on the Holocaust and more recently in Weitz, Mann, and Mark Levene's comparative research. ${ }^{19}$

While not comprehensive, these six streams of argumentation reflect the diversity, heterogeneity, and sophistication of comparative research on genocide and related forms of mass killing. In the past decade in particular, macro-level research and theorization has expanded significantly. In comparison to research at the meso and micro levels, macro-level research is explicitly comparative; it is often cross-national and crosstemporal. While a number of problems continue to limit the coherence of the field (as discussed below and perhaps as would be expected given the interdisciplinary nature of the field and the complexity of the phenomenon), we underline here that much of the dynamism in the literature on the origins of genocide in recent years has occurred at the macro level. This makes sense. Because genocide is usually a top-down process, in which national states are initiators and authorizers of mass violence, theorizing causation at the macro level is a natural fit for genocide studies. At the same time, the dynamism at the macro level should not overshadow important research agendas at the meso and micro levels. As the article argues, theorizing all three levels should be part of a comprehensive agenda for studies of genocide and similar forms of mass violence.

\section{Meso-Level Research}

What is the meso level? At the broadest level, the meso level is the space between national- or international-level factors and individual-level ones. More specifically, 
meso-level studies typically focus on subnational regions and communities (provinces, towns, and villages) or on specific institutions (such as political parties, civil society organizations, economic sectors, social or political networks, or military units). Compared to macro- and micro-level research, meso-level analysis is the least developed among the three prongs of genocide research, and the field of genocide studies would benefit from greater attention to this level of analysis.

The meso level is crucial for several reasons. First, local-level actors are often critical in how genocide occurs. Local actors transmit and sometimes initiate policies to commit violence, identify and sort victims, and frequently are key perpetrators of actual killing. Coordination between macro-level and meso-level actors is an essential part of the process of genocide. As Bloxham argues, mass murders "are organized, in the sense that the actions of perpetrators are concerted and systematic. An organizational structure usually emerges-however rudimentary or temporary." ${ }^{20}$ Meso-level actors are essential to that process. Second, meso-level actors shape the process of violence, in particular in more decentralized states. In highly centralized and coercive states, meso-level actors might enjoy comparatively little autonomy in substantially changing or altering the trajectory of mass violence. But in other circumstances meso-level actors have greater independence. Their actions in turn can shape, amplify, and inhibit agency and victimization. ${ }^{21}$ Third, by looking carefully at the meso level, scholars can develop a richer understanding of the dynamics of violence and generate evidence by which to evaluate competing hypotheses. Fourth, studying meso-level institutions will yield insight into variation into how and why violence unfolds at different levels or in different ways, as the civil war literature has recently demonstrated. ${ }^{22}$ Pioneered by Stathis Kalyvas and Elisabeth Wood, a focus on local dynamics has been a central innovation in the literature on violence in civil war. ${ }^{23}$ In particular, Kalyvas argues that the national and the local level should be disarticulated and that the dynamics at the local level are often not derivative of the broader or "master" cleavages at the national level.

To be sure, the meso level has not been completely overlooked by scholars, in particular scholars of the Holocaust. Our understanding of the Holocaust has been vastly improved by classic community studies (such as Jan Gross's Neighbors), studies of Einsatzgruppen and various Nazi institutions, and recent works, such as Christopher Browning's Remembering Survival and Barbara Engelking and Jacek Leociak's monumental study of the Warsaw ghetto. ${ }^{24}$ Often authored by historians, the principal goals of these studies were to describe what happened in these communities.

But some recent work on Eastern Europe in the 1940s has been undertaken with more explicit explanatory and theoretical objectives. One innovative study focuses on the summer of 1941 when numerous Jews were murdered not by the Nazis but by their non-Jewish neighbors. These pogroms and collective killings were not formally part of the Nazi-initiated genocide. But by studying variation in where the violence occurred, Jeffrey Kopstein and Jason Wittenberg develop a rich argument about how the outburst, or the lack thereof, of anti-Jewish violence is related to pre-existing patterns of politics and modes of intercommunal relations between the Jewish minority and their nonJewish neighbors. According to their findings,

[in places] where Jews supported ethnic parties that advocated minority cultural autonomy, the local populations perceived the Jews as an obstacle to the creation of a nationstate in which minorities acknowledged the right of the titular majority to impose its culture across a country's entire territory. These communities became toxic. Where 
determined state elites could politically integrate minorities, pogroms were far less likely to occur. ${ }^{25}$

Their findings echo a similar study by Diana Dumitru and Carter Johnson, which focuses on variation in the levels of violence against Jews during World War II. ${ }^{26}$

Subnational variation has been broached in studies of other cases, in particular the 1994 genocide in Rwanda but also violence in Bosnia. ${ }^{27}$ In Rwanda, there is observed variation with respect to when violence started in different communities and in the composition of the local actors driving the genocide. Several scholars have designed studies at the subnational level to focus on the variation in patterns of violence, whether at the commune (district) or secteur (sector) levels. ${ }^{28}$ Those studies have yielded insights into how the process of violence unfolded in Rwanda and have also allowed for a more empirically rich assessment of competing hypotheses that would explain the dynamics of genocide in Rwanda.

A major recent meso-level study on the Rwandan Genocide is Timothy Longman's analysis of churches. By carefully examining one institution, Longman's study provides a rich understanding of the social dynamics and the processes by which violence unfolded and was legitimized. Longman argues that not only were mainstream Christian churches complicit in the Rwandan Genocide of 1994 but their actions facilitated and sometimes encouraged the mass violence. He argues that the churches' embrace of ethnic politics and subservience created fertile ground for the execution of genocide. Longman also conducts a comparative study of the dynamics of genocide in two parishes. In one parish, local actors worked with the state before and during the genocide, singling out Tutsi, labeling them as the accomplices of insurgents, and, finally, murdering them. In the other, the dominant local actors and many common villagers resisted the state's murderous policies. Rwanda is a highly centralized state, and at the end of the day the Tutsi of this parish were also slaughtered. But through his comparison, he effectively illustrates the dynamics of violence and shows that there were important attempts to resist the genocide. ${ }^{29}$

Another recent study by Yang Su focuses on rural China during the Cultural Revolution. In that case, as many as three million people labeled "class enemies" were brutally murdered by their neighbors in collective killings and "struggle rallies." This happened even though the central government had not issued any mass killing orders or policies. Drawing on the social movements literature, and viewing collective killing as an extreme form of collective action, Su proposes a community model to explain why and how a community mobilizes to kill its members. Su also points to and seeks to explain subnational variation in victimization rates. Su's community model considers five related processes to be crucial for collective killing to take place. The first concerns collective ethnic categorization, which is shaped by the community's history, tradition, and culture. The second process generates potential victims in the community, and the third process generates potential killers in the community. The fourth process is the demobilization of legal constraints in the community, while the fifth process is the demobilization of moral constraints and the framing of the situation in terms that make killing possible. However, while some processes-such as scapegoating of so-called class enemies, mass mobilization of the population, and fierce competition between party factions and cadres-affected the state as a whole, in the bloodiest provinces of Guangdong and Guangxi these national-level dynamics were superimposed on and interacted with distinctively local factors, such as a unique history of Chinese migration to these areas, 
patterns of local clan conflicts and village level politics, and the strategic location of the provinces. The outcome was mass killing and only the combination of national and local factors can explain why in Guangdong and Guangxi the killing rates were substantially higher than in the rest of the country. ${ }^{30}$

Finally, the interplay between national- and local-level factors is a theme in Geoffrey Robinson's recent study of East Timor. Robinson, a historian and member of the UN's political team in East Timor in 1999, does not simply see the conflict in dichotomous terms between the Indonesian government, on one hand, and the East Timorese, on the other. He argues that the violence has roots in conflicts between different groups of East Timorese as well as in the patterns of governance and warfare of the Portuguese colonial administration. The Indonesian political and military elite based in Jakarta, argues Robinson, turned to a strategy of mass murder when challenged but could not carry out massacres and terror without local militia. The latter, in turn, were often driven by local factors, histories, and traditions which in many cases predated and were unrelated to the master cleavage of independence from or integration with Indonesia. ${ }^{31}$

Although the meso-level study of genocide or other forms of mass violence remains underdeveloped vis-à-vis other areas of research, our brief consideration here shows how valuable these studies are. Meso-level research from various corners of the world brings into focus key institutions, patterns of interaction before mass violence starts, and detailed attention to how the dynamics of violence unfold. In some cases, as in Poland and China, meso-level factors substantially explain variation in outcomes. But in all the cases, an explicit focus on meso-level factors generates a fuller, richer picture of the process of violence and allows for grounded theorization into the causal dynamics at hand.

\section{Micro-Level Research}

Why do individuals participate in mass violence against civilians? Why do individuals harm others with whom they have no prior individual conflict or who are not engaged in conflict? The question is a perennial and critical concern for scholars of genocide and mass violence. In recent years, the topic has received a systematic review from psychologist James Waller. ${ }^{32}$ There also has been a series of studies on Rwanda as well as an ethnographic study on Cambodia under the Khmer Rouge. ${ }^{33}$ From a comparative perspective, two main weaknesses of micro-level research are (1) the relative absence-with some exceptions - of systematic comparison across cases and (2) an empirical focus on the Holocaust and Rwanda. There is a paucity of systematic data at the individual level on most other cases. A major question that remains unanswered is whether and how agents of violence in cases of mass killing and genocide differ systematically from agents of violence in atrocities of lower magnitude. More specifically, are there patterns of perpetrator composition or individual-level motivation that are specific to cases of mass killing and genocide? Once again, to answer that question, a greater engagement with the broader literature on political violence is necessary.

There are six main methods that scholars of genocide and mass killing have used to make observations at the individual level: (1) compiling biographies or social composition studies through court documents, newspaper coverage, and/or historical accounts of events ${ }^{34}$; (2) in-depth interviews with selective, non-systematically sampled perpetrators $\mathrm{s}^{35}$; (3) close observation of particular actors ${ }^{36}$; (4) experimental designs $\mathrm{s}^{37}$; (5) survey research ${ }^{38}$; and (6) community-based studies that derive observations about individuallevel motivations. It is hard to prescribe any one method. Scholars choose their research methods depending on the questions that they are asking and the data available. 
Theories of why individuals participate in mass violence abound and can perhaps be productively synthesized into eight main categories of argumentation. There are claims about (1) psychological predisposition, such as sadism, to commit violence ${ }^{39}$; (2) deprivation and frustration and in particular the idea that hardship causes stress that is channeled into violence ${ }^{40}$; (3) identity, in particular the idea that individuals harbor outgroup antipathy or in-group solidarity which would lead them to harm others ${ }^{41}$; (4) ideological conviction and commitment ${ }^{42}$; (5) legitimacy-perpetrators commit violence because of their obedience to or vertical relationships with superiors ${ }^{43}$; (6) collective and horizontal peer pressure ${ }^{44}$; (7) fear and insecurity ${ }^{45}$; and (8) selective and material incentives-the idea that individuals commit violence to gain power or property. ${ }^{46}$

Are there any cumulative findings in this theoretically diverse literature? To our minds, there are at least two consistent findings. The first is that the perpetrators of atrocities are "normal" - that is, they often reflect a demographic cross-section of their societies. There is nothing a priori that would have predisposed the average perpetrator to commit violence. The agents of violence do not appear, on average, to have any preexisting, demonstrated psychological abnormality or predisposition to deviance; they do not seem on average to be especially poor; and they have common levels of education. Demographically, they tend to be representative of their societies. The theme is recurrent across some of the most influential micro-level studies, from Waller to Arendt, Browning, and Goldhagen. ${ }^{47}$ This is not to say that some professions are not especially represented in certain aspects of genocide, such as a scientific community in conceiving and implementing the Final Solution. ${ }^{48}$

A second finding concerns heterogeneity at the micro level. A number of scholars who study individual-level behavior conclude that there are multiple dynamics of motivation. Some individuals might have multiple reasons to participate in violence. Others might participate at one point in time for one reason but continue at another point in time for another reason-that is, motivation changes over time. Finally, genocides and other instances of mass killing are complex social and political phenomena in which often thousands of perpetrators take part; no single theory is likely to explain each perpetrator's motivation. Thus, heterogeneity, complexity, and mutability all characterize the findings about perpetrators of mass killing and other forms of extreme violence. ${ }^{49}$

\section{Future Research}

In this section we summarize the main achievements and shortcomings of scholarship at each level of analysis and then suggest new questions and agendas for further research. For a field dominated by macro-level studies, the most fundamental gains have been in understanding which factors lead to genocide; under which conditions leaders turn to mass killings; and how ideologies, emotions, and beliefs contribute to the emergence of genocidal policies. However, despite numerous and quite substantial gains, macro-level scholarship on genocide suffers from several important shortcomings.

First, conceptual disagreements limit the ability to generate cumulative findings. In particular, scholars both maintain different definitions of genocide and use different terms to talk about it. Rummel analyzes "democides," Harff discusses "politicides" (and genocides), and Mann focuses on "murderous ethnic cleansing." Valentino examines mass killings of 50,000 victims over the course of five years, while Shaw argues that the actual number of people murdered matters less than the intention "to shatter and break up" the community's social existence; one should not confuse ends with means and outcomes, he contends. ${ }^{50}$ Some scholars, such as Christian Gerlach, question the theoretical 
usefulness of the concept of genocide. ${ }^{51}$ Achieving scholarly consensus on the concept of genocide or whether genocide should be the unique focus of study (as opposed to another term or a broader category) is probably unlikely. Certainly, debate and disagreement are productive for scholarship. However, as long as there remain core and vigorous disagreements about the main concept that unites a field of study, the ability to make theoretical generalizations about causes will be constrained. At best, scholars working in the field must remain attentive to the conceptual differences that shape it.

Second, macro-level qualitative comparative scholarship on genocide, with some minor and notable exceptions, ${ }^{52}$ is characterized by insufficient attention to variation. The main question in the field is, What do $\mathrm{X}$ cases of genocide have in common? In contrast, there is comparatively little macro-level research that seeks to build on existing findings and theory to explain why some cases result in genocide while others do not. Many theories suffer from what we call a "frequency mismatch" in the sense that the explanations point to conditions that are much more common than the phenomenon of genocide is. In short, there is a critical need for more attention to negative cases-"dogs that did not bark" - that did not result in genocide, which in fact are the norm. Genocide is a comparatively rare outcome.

A third and related shortcoming is that scholarship pays insufficient attention to temporal factors. A number of studies point to a dynamic of escalation, or "cumulative radicalization," as central to the process that leads to genocide ${ }^{53}$ Some studies point to the importance of stages of genocide or to the idea that genocides are "final" solutions. ${ }^{54}$ These studies strongly imply that the steps taken in the planning and execution of genocide are not automatic; rather, they constitute a process. Thus, there are several critical but underexplored comparative questions: What explains escalation? Why do key decision makers choose to escalate rather than de-escalate? Are there commonalities across cases that seem different in negative cases? These questions imply a strong need for the temporal disaggregation of cases. But, with some notable exceptions, ${ }^{55}$ these types of temporal, disaggregated questions are rarely asked in a comparative context. The absence is all the more surprising given that the majority of comparative research is qualitative, small $N$ research whose hallmark should be process tracing.

Three final related concerns at the macro level are (1) insufficient attention to issues of restraint, (2) problems of unit heterogeneity, and (3) an unhealthy division from studies of political violence.

With regard to the first issue, much of the existing macro-level literature focuses on those conditions that would prompt leaders and societies to commit genocide. ${ }^{56} \mathrm{But}$ if the operative question becomes why does genocide occur in some locations and at some times but not in other locations or at other times, an equally important question asks what prompts leaders to avoid or moderate the use of mass violence. ${ }^{57}$

The issue of unit heterogeneity is the idea that the cases being compared are empirically quite different. The Armenian Genocide, Rwanda, and the Holocaust are three of the common cases of comparison in the comparative literature on genocide. Yet in terms of the historical period, region, territory, economy, demographic structure, and even the nature of the violence, these cases differ dramatically. To continue to build theory, tighter comparisons that hold more variables constant will be important.

Finally, the study of genocide should not be cloistered from studies of political violence or violence in civil war. At base, studies of genocide share a great amount of substantive overlap with studies of other forms of violence-riots, assassinations, 
massacres, the targeting of civilians in war, ${ }^{58}$ counterinsurgency, general strategy-yet there is little intellectual interaction between these obviously related areas of inquiry. Again, a key issue concerns isolating and explaining the specificity of genocide by embedding the analysis in the study of kin phenomena.

We have argued that meso-level research is the least developed branch of genocide scholarship, but meso-level single-country and comparative research is a promising emerging research area. Concentrating on the meso level, where national-level policies and decisions translate into individual actions on the ground, will provide the field with a better understanding of causal chains and mechanisms. In other words, the meso level is an essential link between the macro and micro levels, without which our ability to analyze genocides will be significantly restrained.

Furthermore, meso-level research has the ability to overcome some problems associated with macro-level scholarship. First, meso-level research often explicitly incorporates variation into the research design. In particular, for community-based research, the question is, What explains variation in outcomes across different regions and communities? Second, the analysis of subnational units creates greater possibilities for large $N$ statistical analysis, which in genocide studies is often constrained either by unit heterogeneity or by a small number of cases. Third, subnational meso-level comparative analysis holds national-level factors constant, and in so doing meso-level analysis lends itself to identifying factors that independently cause variation.

Yet, there are important limitations to meso-level analysis. First, it cannot explain why, when, and under which conditions genocide takes place. Meso-level research should not treat genocides as only or mainly local and should not underestimate the role of macro-level factors, namely state policies and actions. At the end of the day, genocide most often is top-down. ${ }^{59}$ Second, it is still unclear how to differentiate local violence during genocide from instances of local violence that are not genocidal in nature, such as ethnic riots, pogroms, or localized massacres. At the same time, by concentrating on local factors and conditions and by comparing different units, institutions, regions, and communities, future meso-level research can play a key role in bridging macro- and micro-level scholarship and improving our understanding of how, why, and under which conditions a government's vague and often murky orders of extermination are translated into actual killings on the ground.

Micro-level research will likely remain an area of continued attention. Many analysts want to understand and explain how ordinary people commit terrible acts of atrocity. What then are some avenues for future research to strengthen this area of analysis? Studies of genocide perpetrators often do not provide systematic explanations of variation among potential perpetrators. Why do some individuals participate in mass violence while others do not? Micro-level research often does not consider the whole spectrum of potential behavioral strategies and does not explain what accounts for the adoption of each strategy. Furthermore, as noted above, two cases now empirically dominate the literature-the Holocaust and Rwanda (the former much more than the latter)-and there is relatively little systematic comparison across countries and time periods. Finally, we note the relative absence of new insights from the social psychology literature and the relative absence of contemporary experimental design in the study of genocide. ${ }^{60}$

To summarize, we envision further research that applies both qualitative and quantitative methods, is embedded in the broader political violence literature, pays sufficient 
attention to and seeks to explain variation in outcomes, concentrates on identifying causal mechanisms and tracing causal chains, and combines different levels of analysis with particular attention to developing meso-level analysis. These changes will continue to help advance research on the origins and dynamics of genocide and mass killing while putting the field in closer methodological and theoretical conversation with related areas of research in the social sciences and history.

Evgeny Finkel is a PhD candidate, Department of Political Science, University of Wisconsin, Madison, and a Research Fellow, Program on Order, Conflict, and Violence, Yale University. His articles have been published in Comparative Politics, Global Society, East European Politics and Societies, and Democratization.

Scott Straus is Professor of Political Science and International Studies at the University of Wisconsin, Madison. His most recent book is Remaking Rwanda: State Building and Human Rights after Mass Violence (U of Wisconsin P, 2011), which he co-edited with Lars Waldorf.

\section{Notes}

1. Scott Straus's research was supported by a generous grant from the Harry Frank Guggenheim Foundation.

2. Leo Kuper, Genocide: Its Political Use in the Twentieth Century (New Haven: Yale UP, 1981); Helen Fein, Accounting for Genocide: National Responses and Jewish Victimization during the Holocaust (New York: Free Press, 1979); Israel Charny, How Can We Commit the Unthinkable? Genocide, the Human Cancer (Boulder, CO: Westview, 1982); Irving Louis Horowitz, Genocide: State Power and Mass Murder (New Brunswick, NJ: Transaction, 1976).

3. The arguments in this article build on, but to go beyond, earlier appraisals by one of the authors. For related claims, see Scott Straus, "Second-Generation Comparative Research on Genocide," World Politics 59,3 (2007): 476-501; Scott Straus, "Political Science and Genocide," in The Oxford Handbook of Genocide Studies, ed. Donald Bloxham and A. Dirk Moses (New York: Oxford UP, 2010), 163-81; Scott Straus, "Destroy Them to Save Us': Theories of Genocide and the Logics of Political Violence," Terrorism and Political Violence (forthcoming 2012).

4. Our article does not address other important areas of research in the genocide studies field, from questions of intervention and prevention to questions of criminal responsibility and questions of the aftermath of such atrocities, among other related topics.

5. Straus, "Second-Generation Comparative Research."

6. Kuper, Genocide.

7. Fein, Accounting for Genocide.

8. Daniel J. Goldhagen, Hitler's Willing Executioners: Ordinary Germans and the Holocaust (New York: Knopf, 1996); Daniel J. Goldhagen, Worse than War: Genocide, Eliminationism, and the Ongoing Assault on Humanity (New York: Public Affairs, 2009).

9. John Hagan and Wenona Rymond-Richmond, Darfur and the Crime of Genocide (New York: Cambridge UP, 2008).

10. Horowitz, Genocide: State Power and Mass Murder; Rudolph Rummel, Death by Government (New Brunswick, NJ: Transaction, 1994).

11. Barbara Harff, "No Lessons Learned from the Holocaust? Assessing Risks of Genocide and Political Mass Murder since 1955," American Political Science Review 97,1 (2003): 57-73; Kristine Eck and Lisa Hultman, "One-Sided Violence Against Civilians in War: Insights from New Fatality Data," Journal of Peace Research 44,2 (2007): 233-46; Jay Ulfelder and Benjamin Valentino, "Assessing Risks of StateSponsored Mass Killing," Political Instability Task Force, 2008, http://papers.ssrn.com/sol3/papers.cfm? abstract_id=1703426 (accessed 14 Feb 2012); Matthew Krain, "State Sponsored Mass Murder: The Onset and Severity of Genocides and Politicides," Journal of Conflict Resolution 41,3 (1997): 331-60.

12. Ervin Staub, The Roots of Evil: The Origins of Genocide and Other Group Violence (Cambridge: Cambridge UP, 1989); Peter Uvin, Aiding Violence: The Development Enterprise in Rwanda (West Hartford: Kumarian, 1998).

13. Barbara Harff, "The Etiology of Genocides," in Genocide and the Modern Age: Etiology and Case Studies of Mass Death, ed. Isidor Walliman and Michael Dobkowski (Westport: Greenwood, 1987), 41-59.

14. Eric D. Weitz, A Century of Genocide: Utopias of Race and Nation (Princeton: Princeton UP, 2003); Michael Mann, The Dark Side of Democracy: Explaining Ethnic Cleansing (New York: Cambridge UP, 2005); Ben Kiernan, Blood and Soil: A World History of Genocide and Extermination from Sparta to 
Darfur (New Haven: Yale UP, 2007); Jacques Semelin, Purify and Destroy: The Political Uses of Massacre and Genocide (New York: Columbia UP, 2007).

15. Donald Bloxham, The Great Game of Genocide: Imperialism, Nationalism, and the Destruction of the Ottoman Armenians (Oxford: Oxford UP, 2005).

16. Benjamin Valentino, Final Solutions: Mass Killing and Genocide in the Twentieth Century (Ithaca: Cornell UP, 2004); V.P. Gagnon, The Myth of Ethnic War: Serbia and Croatia in the 1990s (Ithaca: Cornell UP, 2004).

17. Manus I. Midlarsky, The Killing Trap: Genocide in the Twentieth Century (Cambridge: Cambridge UP, 2005).

18. Martin Shaw, War and Genocide: Organized Killing in Modern Society (Cambridge: Polity, 2003); Benjamin Valentino, Paul Huth, and Dylan Balch-Lyndsay "Draining the Sea: Mass Killing, Guerrilla Warfare," International Organization 58,2 (2004): 375-407; Ulfelder and Valentino, "Assessing Risks of State-Sponsored Mass Killing." For an earlier linkage between war and genocide, see Robert Melson, Revolution and Genocide: On the Origins of the Armenian Genocide and the Holocaust (Chicago: U of Chicago P, 1992).

19. Zygmunt Bauman, Modernity and The Holocaust (Ithaca: Cornell UP, 1989); Weitz, A Century of Genocide; Mark Levene, Genocide in the Age of the Nation State (London: I.B. Tauris, 2005); Mann, The Dark Side.

20. Donald Bloxham, "Organized Mass Murder: Structure, Participation, and Motivation in Comparative Perspective," Holocaust and Genocide Studies 22,2 (2008): 203-45, 203.

21. Ibid., 218.

22. Stathis Kalyvas, "The Ontology of 'Political Violence': Action and Identity in Civil Wars," Perspectives on Politics 1,3 (2003): 475-94; Stathis Kalyvas, The Logic of Violence in Civil War (New York: Cambridge UP, 2006); Charles King, "The Micropolitics of Social Violence," World Politics 56,3 (2004): 431-55.

23. Kalyvas, "The Ontology of 'Political Violence"; Kalyvas, The Logic of Violence in Civil War; King, "Micropolitics of Social Violence"; Elisabeth Jean Wood, Insurgent Collective Action and Civil War in El Salvador (New York: Cambridge UP, 2003).

24. Jan T. Gross, Neighbors: The Destruction of Jewish Community in Jedwabne, Poland (New York: Penguin, 2002); Michael Thad Allen, The Business of Genocide: The SS, Slave Labor, and the Concentration Camps (Chapel Hill: U of North Carolina P, 2002); Christopher Browning, Remembering Survival: Inside a Nazi Slave-Labor Camp (New York: Norton, 2010); Barbara Engelking and Jacek Leociak, The Warsaw Ghetto: A Guide to the Perished City (New Haven: Yale UP, 2009).

25. Jeffrey Kopstein and Jason Wittenberg, "Deadly Communities: Local Political Milieus and the Persecution of Jews in Occupied Poland," Comparative Political Studies 44,3 (2011): 259-83.

26. Diana Dumitru and Carter Johnson, "Constructing Interethnic Conflict and Cooperation: Why Some People Harmed Jews and Others Helped Them During the Holocaust in Romania," World Politics 63,1 (2011): 1-42.

27. On Bosnia, see Fotini Christia, "Following the Money: Muslim versus Muslim in Bosnia’s Civil War," Comparative Politics 40,4 (2008): 461-80. Christia emphasizes the importance of the local elite in explaining variation in how communities responded during the civil war.

28. Lee Ann Fujii, Killing Neighbors: Webs of Violence in Rwanda (Ithaca: Cornell UP, 2009); Omar McDoom, The Micro-Politics of Mass Violence: Authority, Security, and Opportunity in Rwanda's Genocide (PhD Diss., London School of Economics, 2009); Scott Straus, The Order of Genocide: Race, Power, and War in Rwanda (Ithaca: Cornell UP, 2006).

29. Timothy Longman, Christianity and Genocide in Rwanda (New York: Cambridge UP, 2010).

30. Yang Su, Collective Killings in Rural China during the Cultural Revolution (New York: Cambridge UP, 2011).

31. Geoffrey Robinson, 'If You Leave Us Here, We Will Die': How Genocide Was Stopped in East Timor (Princeton: Princeton UP, 2009)

32. James Waller, Becoming Evil: How Ordinary People Commit Genocide and Mass Killing (New York: Oxford UP, 2002).

33. On the latter, see Alexander Laban Hinton, Why Did They Kill? Cambodia in the Shadow of Genocide (Berkeley: U of California P, 2005).

34. Examples from the Holocaust include Christopher Browning, Ordinary Men: Reserve Police Battalion 101 and the Final Solution in Poland (New York: Harper Perennial, 1993); Dick de Mildt, In the Name of the People: Perpetrators of Genocide in the Reflection of Their Post-War Prosecution in West Germany: The 'Euthanasia' and 'Aktion Reinhard' Trial Cases (The Hague: Martinus Nijhoff, 1996); Mann, The Dark Side. 
35. Examples include Fujii, Killing Neighbors; Robert Jay Lifton, The Nazi Doctors: Medical Killing and the Psychology of Genocide (New York: Basic Books, 1986); and Hinton, Why Did They Kill?

36. Examples include Hannah Arendt, Eichmann in Jerusalem; A Report on the Banality of Evil (New York: Viking, 1963); David Cesarani, Eichmann: His Life and Crimes (London: Heinemann, 2004); Hervé Deguine, Un idéologue dans le génocide rwandais: Enquête sur Ferdinand Nahimana (Paris: Mille et Une Nuits, 2010).

37. The most influential social psychology experiments for the study of genocide are those by Stanley Milgram and Philip Zimbardo. See Milgram, Obedience to Authority: An Experimental View (New York: Harper \& Row, 1974); Zimbardo, The Lucifer Effect: Understanding How Good People Turn Evil (New York: Random House, 2007).

38. Examples include McDoom, The Micro-Politics of Mass Violence; Straus, The Order of Genocide. For a focus on Sierra Leone, see Macartan Humphreys and Jeremy Weinstein, "Who Fights? The Determinants of Participation in Civil War," American Journal of Political Science 52,2 (2008): 436-55.

39. For a smart review, see Waller, Becoming Evil.

40. Staub's The Roots of Evil and Uvin's Aiding Violence are classic statements on this mechanism.

41. For illustrative examples, see Goldhagen, Hitler's Willing Executioners and Donald Horowitz, The Deadly Ethnic Riot (Berkeley: U of California P, 2001).

42. Mann, The Dark Side.

43. Browning, Ordinary Men, in part based on Milgram's Obedience to Authority. See also Herbert Kelman and V. Lee Hamilton, Crimes of Obedience: Towards a Social Psychology of Authority and Responsibility (New Haven: Yale UP, 1989).

44. See also Browning's Ordinary Men and Straus's The Order of Genocide. Fujii's Killing Neighbors stresses social networks.

45. Straus, The Order of Genocide; McDoom, The Micro-Politics of Mass Violence.

46. de Mildt, In the Name of the People; Neil Mitchell, Agents of Atrocity: Leaders, Followers, and the Violation of Human Rights in Civil War (New York: Palgrave Macmillan, 2004); Humphreys and Weinstein, "Who Fights?"

47. In The Order of Genocide, Straus also stresses this point with regard to Rwanda.

48. On this point, see Gotz Aly, "The Planning Intelligentsia and the 'Final Solution,'” in The Holocaust: Origins, Implementation, Aftermath, ed. Omer Bartov (London: Routledge, 2000), 92-105.

49. For some explicit statements on this theme or implicit claims in which multiple motivations are at work, see Roy Baumeister, Evil: Inside Human Violence and Cruelty (New York: W.H. Freeman, 1997); Browning, Ordinary Men; and Humphreys and Weinstein, "Who Fights?"

50. Martin Shaw and Omer Bartov, "The Question of Genocide in Palestine, 1948: An Exchange between Martin Shaw and Omer Bartov," Journal of Genocide Research 12,3 (2010): 243-59, 244, 248-9. See also Mann, The Dark Side; Valentino, Final Solutions.

51. Christian Gerlach, Extremely Violent Societies: Mass Violence in the Twentieth-Century World (Cambridge: Cambridge UP, 2010).

52. Midlarsky, The Killing Trap; Mann, The Dark Side.

53. Bloxham, The Great Game of Genocide.

54. Gregory Stanton, "8 Stages of Genocide," in The Genocide Studies Reader, ed. Samuel Totten and Paul Bartrop (New York: Routledge, 2008), 127-29; Valentino, Final Solutions.

55. Deborah Mayersen, "On the Timing of Genocide," Genocide Studies and Prevention 5,1 (2010): 20-38, http://dx.doi.org/10.3138/gsp.5.1.20; Mann, The Dark Side.

56. For an exception, see Mayersen, "On the Timing of Genocide."

57. For an elaboration of this point, see Scott Straus, "Retreating from the Brink: Theorizing Mass Violence and the Dynamics of Restraint," Perspectives on Politics (forthcoming Jun 2012).

58. On this point, see Alexander Downes, Targeting Civilians in War (Ithaca: Cornell UP, 2008).

59. An example of research that brings the meso level into dialogue with the top-down nature of genocide is Bloxham, "Organized Mass Murder."

60. An exception to the former is Midlarsky, The Killing Trap. 